poor, it is quite impossible for the leeway to be made up during the period of the year when temperate cattle are not affected by the climatic conditions. In the case of the animal surviving, it virtually exists in a state of chronic undernourishment.

Although animal breeding still presents many problems, both genetical and physiological, the knowledge gained from scientific approaches to the subject during the past three decades has made it considerably more exact and practicable. Scientific investigations provide the evidence to prove that the high-grade European breeds of cattle, which are the result of selection for maximum performance under temperate climatic conditions, do not maintain the same qualities when transferred beyond the borders of their natural habitat or of regions with approximately similar conditions. Hence, improvement of animal production by merely replacing the cattle native to tropical and sub-tropical regions with highly improved breeds of temperate origin is out of the question.

'The genetical variation occurring within the exotic breeds makes possible the selection of individuals possessing those attributes required for increased adaptability to tropical conditions. By basing their selection on such characters as coat covering and colour, Bonsma and his associates have achieved considerable success in increasing the heat tolerance of British beef breeds, especially Herefords, at the Mara Research Station, which is situated in the dry-tropical zone of South Africa. The limit of such a policy is indicated, however, by the fact that when these investigations were repeated at the Messina Experimental Farm, situated in a lowerlying tropical belt, they met with complete failure. The high mortality-rate of the British beef breeds in the tropics, compared with the indigenous stock, also seriously limits the value of breeding adapted strains of European cattle.

Cross-breeding between the indigenous stock and exotic types presents a second possibility. During the early stages of livestock improvement in tropical regions, a policy of grading up with European breed bulls was advocated. The first generation cross-breds excelled because of hybrid vigour and the genetical dominance of heat-tolerant characters; as the percentage of indigenous blood diminished in subsequent generations, the cross-breds also deteriorated.

The most constructive and successful of all long. term policies for livestock breeding in tropical and sub-tropical regions seems to lie in improvement of the indigenous stock by means of judicious selection. The high standard of animal production of temperate countries can never be attained in tropical regions, while the indigenous stock of the tropics are inherently of lower productivity than their cousins of the temperate zone. Nevertheless, in the Afrikaner, it has been demonstrated that improvement of beef qualities is possible without any loss of those characters which give the breed superiority over exotic types in the tropies and sub-tropics. As for its slower growth and maturing characters, these actually are inherent qualities of practical significance and value in the production of beef under varying conditions of climate, and especially nutrition. As a result of a slower growth-rate, the influence of periodic nutritional depressions is not so acute as is the case with the rapidly growing, early-maturing breeds of beef cattle.

\section{LIBRARY CO-OPERATION IN BRITAIN}

$\mathrm{T}$

HE final recommendations on Library Cooperation of the Joint Working Party set up by the National Central Library and the National Committee on Regional Library Co-operation have now been issued in the name of the Library and the National Committee*. The working party was satisfied that the general structure of library cooperation and inter-lending is sound, and recommended that university and special libraries outside the area covered by the London Union Catalogue and the South Eastern Region should become participant members of their appropriate regional system on the basis on which many of them at present co-operate, and that they should also retain the existing right to send applications direct to the National Central Library. Within this area, however, it recommends that, as at present, university libraries should apply direct to the National Central Library for inter-library loans, but special libraries should have direct relations with the Central Library; and that membership of the London and South Eastern Regional Library systems should remain restricted to the public library authorities within the area.

The working party is also satisfied that the Union Catalogue is necessary for effective inter-lending, and recommends that the existing Union Catalogue should be brought up to date. The Yorkshire, North Western and West Midland Regions should consider how best they may provide Union Catalogues of stock prior to a specified date, which would be adequate for regional and national purposes, and from that date all regional union catalogues should contain entries for British books, and for all other books published outside Great Britain, and those published in Great Britain prior to the specified date. The working party also recommends that each region should consider what co-operative arrangements could be made to ensure that all applications to the bureaux for current British material are supplied from resources within the region, and to ensure that at least one copy of every non-fiction book in the region is retained permanently in that region. Each region should also investigate the methods by which the range of periodicals can be improved and their permanent preservation ensured.

The working party recommends the exclusion from the scope of all inter-lending agencies of: $(a)$ those works of English and American fiction outside the scope of the joint fiction reserves to be set up in the various regions; $(b)$ sets of copies of plays for acting and reading outside the scope of any joint play collections to be set up in the regions; (c) children's books ; $(d)$ 'quick reference' books (that is, dictionaries, atlases, encyclopædias, etc., likely to be regularly consulted in a library); (e) current yearbooks, annuals and directories; $(f)$ current numbers of periodicals.

It also suggests that all books in print costing 258 . or less should be outside the scope of the National Central Library.

The working party considers that any long-term plans for bringing these regional bureaux to a state of greater efficiency and maintaining them adequately

- Recommendations on Library Co-operation. Pp. 8. (London: National Central Library and National Committee on Regional Library Co-operation, 1954.) 
should attract a grant from H.M. Treasury. It is indicated that the National Central Library proposes to institute, in consultation with the National Institute of Adult Education and the other bodies concerned, an inquiry into the present provision of books for adult education classes, with the view of considering how far the type and the extent of the services require modification.

\section{THE FILM AND THE SOCIAL SCIENCES}

$\mathrm{A}$

LTHOUGH film processes are being increasingly used for research in the physical and biological sciences, little attention is paid to the cinema as a medium for investigating, teaching and propagating new knowledge in the social sciences (Science and Film, 3, No. 2; June 1954). This may perhaps arise from an old-fashioned but not entirely played-out attitude of disdain for the place to be given, within the hierarchy of knowledge, to the study of human relations and human behaviour. An over-narrow view of the film-medium itself may also at times colour our outlook on its applications to science. The camera has, of course, special qualities for the observation of time and of mechanical movement, and the roles it can fulfil in the 'exact' sciences are obvious. But its usefulness does not end there.

The camera as an instrument of research in the social sciences has so far been little developed. Even for investigating manipulative processes, of such demonstrable value to the study of workshop skills and of industrial conditions generally, its use still remains the exception rather than the rule. For more subtle and less tractable problems of human behaviour, its use has been even less explored. Two recent examples of the use of the camera in psychological inquiry - of maternal separation and of the reactions of children to the cinema-illustrate well some of the possibilities. A rather similar, though brief, use of the motion-picture camera occurred in "Children Learning by Experience", itself a remarkable 'anthology' of children's behaviour as an aid in the training of teachers. Less normal phenomena form the subject of a pioneer Canadian series of filmed case-histories for the use of psychopathologists. Here the camera, records permanently, unobtrusively and 'objectively'. To take another branch of the social sciences, no subject offers perhaps so wide a scope for the film record as does anthropology. Among rnany instances, Dr. Mountford's "Tjurunga" and his other films of the Australian stone-age men reflect the interest, not only scientific but also sometimes æesthetic, of such visual reports. Indeed, the trained cinematographer might well be considered an indispensable member of all field-teams engaged in anthropological or ethnological studies.

The dramatic qualities of the film medium are also available to the social scientist for explaining his purposes and methods to the general public. The cinema can illumine, too, the social relations of science; and this is perhaps one of the most important of its functions. There is need for films which will explain to the man in the street what science is, how scientists think and work, and the limits and freedoms affecting their activities. To this task the cinema as an art can bring special qualities of imagination and human warmth.

\section{RESEARCH COUNCIL OF ALBERTA}

\author{
REPORT FOR 1953
}

$\mathrm{T}$ THE thirty-fourth annual report of the Researeh Council of Alberta, to which are appended lists of committees, staff and publications, covers the calendar year $1953^{*}$ and emphasizes a shift in emphasis in coal research towards tho exploration of the chemical potentialities of coal. Besides this a palæobotanical study was made of the flora and biological origin of Alberta coal measures, as well as investigations into the chemical and colloidal structure of coals. The vertical electric tube furnace for the determination of volatile matter in coal, built in 1929, was redesigned and a 14-in. rotating, selfclearing grate and ancillary control and recording equipment, installed in 1952, was used to complete an evaluation of the combustion characteristics of typical Alberta coals; a study of water retention by coal was also completed. Investigation of the trace metals in oil-sands oil and other Alberta oils suggests that occurrence of vanadium and nickel may serve as a precise correlative for crude oils and that cretaceous oils in general have a common origin. Attention is being directed to the origin of the tracemetal carriers, the porphyrins, and studies are proceeding on the properties of the heavy oils of Alberta and the viscosity of dispersions of wet oil containing mineral matter. The survey of the quality of Alberta gasoline continued, further tests were made on the storage of aviation gasoline, and work also continued on the partial oxidation of butane, in which a new reaction system was designed and built, and on the production of carbon black in a tubular furnace.

Field work by the Geological Section included detailed studies of selected areas for uranium in northeastern Alberta, along the north shore of Lake Athabasca, and in the north-central portion of the PreCambrian outcrop area in Alberta and especially north of Fidler Point and Leggo Lake, as well as a Pleistocene study in east-central Alberta. A fundamental mineralogical investigation of montmorillonite, the chief constituent of bentonite, in which forty samples of montmorillonite were subjected to X-ray and differential thermal analysis, indicates that every montmorillonite is a complex and intimate mixture. Further work under the Highway Research Project indicates that the dispersing and other properties of lignosol are important factors, as well as the viscosity effects, in preventing the migration of soil moisture to the frost line, and that sodium hexametaphosphate is equally effective in preventing frost action. Soil surveys were concentrated largely in the Peace River area, and a reconnaissance survey of the Grande Prairie sheet completed the field work on some 750,000 acres. Irrigation research was cornmenced on the solonetzic soils of the projected Red Deer irrigation area to determine the response to irrigation of various methods of treatment.

In the Industrial Projects Section research and testing for industry are of increasing importance. The ten-year biological cycle now appears to have reached the collapse predicted, and various publica. tions on these extensive investigations are now being prepared. Two other investigations in animal science related to the effert of 'management factors' on the

* Thirty-fourth Annua : Report of the Research Council of Alberta, 1953. Pp. 41. (Edmonton: Queen's Printer, 1954.) 